\title{
LEPROSARIUM MAGAZINES
}

J. Ross INNES, M.D., D.T.M., CH.B.

Interterritorial Leprologist, East Africa, and Director, East African Leprosy Research Centre, Busia, Uganda

[The Fontilles Leprosarium is situated between Valencia and Alecante, in an ideal position on the slope of a bill, with an outlook over a fertile plain to the Mediterranean a few miles away. Its name (meaning "small fountains") is derived from the fact that several small springs of cool clear water come gushing out of tine side of the bill in between the buildings of the institution.]

The practice of producing leprosarium magazines is perhaps somewhat neglected in the English-speaking world. I can think of the famous " Star " of Carville, U.S.A., but have difficulty in recalling any others, and shall be delighted if my readers will inform me of any. Yet there is great value in a leprosarium magazine, whether produced by the " Management " and receiving contributions from the patients, or produced entirely by the patients themselves. The life and needs of the patients can become widely known, and refreshed in the public mind, and an insistent course to indoctrination of the public carried on, directed to informing the world of the true nature of the disease.

For some time now I have been receiving "Fontilles," a monthly magazine dealing with the life and affairs of the ColonySanatorium, containing 300 patients, at Fontilles in Spain. This magazine has impressed me so much as an example of what such a publication can be, that I propose to take the latest number to hand, that of June, I955, and describe it more or less page by page, hoping this will stimulate interest and emulation.

The issue of June, I955, contains 32 pages, exclusive of the covers. The size is handy, $9 \frac{1}{2}$ by $6 \frac{3}{4}$ inches. The colour-scheme of the front cover is a simple and tasteful green and white, and it carries a picture $4 \frac{1}{2}$ by $6 \frac{3}{4}$ inches of the laboratory buildings at Fontilles. On page 18 of the text there is given a description of the cover-picture and its subject: this cover-piece is changed every month.

The first page carries an editorial under the heading " Witnesses," and turns out to be a homily with vigour and clarity on the day of St. John Baptist, and what witnessing means. Having absorbed the inspiration of this excellent "sermonette," one 
turns to page 2, on which there is a mixed bag of interest. First there is a quotation in an enclosed column from Lucius Anneus Seneca (a Spaniard himself, by the way) in which he denounces the love of mere physical beauty. Second, there is a paragraph recounting donations during the Valencian carnival season to Fontilles by Valencian well-wishers. Third, in clear type is a quotation from St. Cyril of Alexandria, " He who practises mercy, travels directly to his reward: he who does not practise it, journeys towards punishment." Under this is the direct query, " Do you have mercy to the lazarines?" Fourth, there is a photograph of four cheerful gentlemen, and it is explained that they are the friendly and helpful mayor and councillors of Tormos, a township which is a near neighbour of Fontilles, taken during one of their visits to Fontilles.

On page 3, there is reproduced a prize essay by a boy of the College of Santo Domingo of Orihuela (Alicante). This essay described the impressions made on him by a visit to Fontilles, and is a fine piece of work, containing the striking phrase, "Fontilles is a book whose pages should be read by all men at least once in their life." The boy, Andres de Barcala Muñoz, gave for the welfare of Fontilles the roo pesetas which, with a book, constitutes the prize for this essay!

Also on this page there is the customary column headed " Things needed in Fontilles," in which appeal is made for gifts of money to replace the worn furniture of the dining rooms.

The next two pages are headed " Step by Step " and seem to be one of a series of factual reportings on the internal activities of Fontilles. This one deals with linen and clothing. There is an attractive photograph of the women patients at sewing and mending, accompanied by three Sisters, and the text describes the work of the laundry, the linen room, and the sewing room. No piece of clothing can enter the laundry without passing through the sterilising room. The gowns of workers in the sanatorium are also sterilised here, and also letters written by the patients. The latter is done, it is said, for the peace of mind of the recipients, not because of any real danger of transmission of germs. The women patients who do the work, do it with great cheerfulness, and sing and pray at their task, and at the end of the month receive a modest payment.

Pages 6 and 7 contain a moving tribute to Don Adolfo Bernabeu, a well-loved benefactor of Fontilles, who had died in a motor-bus accident. Two relevant photographs are given, one of the deceased gentleman, and the other depicting a large group of 
workers and employees of his factory on one of their visits to Fontilles. The tribute to Don Adolfo is written by Padre Romaño, S. J., and even a stranger reading it mourns with Fontilles at the loss of such a man and is comforted by the spiritual comfort proffered.

Pages 8 and 9 contain, apart from three commercial advertisements, a report of the collective visit of the Padres of the Third Order, who presented a concert in the theatre for the benefit of the patients and staff, and were helped in this by the coincidental presence of a group of ten medical students from Madrid. It seems to have been a happy occasion. There is also a photograph of a group of other visitors, a number of Valencian young ladies with their Spiritual Director, who came at the conclusion of their course of spiritual exercises. Also, there is a striking appeal in large print in the following words: "In order to rescue children threatened by leprosy, the College-Preventorium of St. Henry takes care of children of leprosy patients: will you help it? Fontilles broadens its work with this foundation in the city of Alcira."

On pages ro and II there are "Notes on a Journey to Fontilles," which are extracted from articles which appeared in the paper " Jornada" of Valencia, by Adolfo Cámara. It is interesting that the outside papers are publishing material on Fontilles, and that their reporters carry and diffuse the truth about Fontilles. This particular example is most excellent, being factual and impressive. Also on page II there is a report about a place called Cuart de Poblet, which staged a festival for the benefit of Fontilles, and handed over I,573 pesetas. After that, for the stranger-reader, there is no need to wonder what sort of a place is Cuart de Poblet! Finally on page II there is a notice requesting subscribers to "Fontilles " to notify any change of address.

On page I2 there are some more commercial advertisements, but the most interesting thing is another appeal for Fontilles, as follows: " All can be subscribers to this magazine; all can collaborate in its pages; all can be friends of Fontilles; but do all know it? propagate the magazine: help Fontilles."

Page I3 contains two delightful pictures of the seven young men patients who are members of the new orchestra at Fontilles. The old orchestra was dissolved because most of its members left Fontilles cured, and it is noteworthy that some of them obtained musical posts in the outside world. The new members face the camera a little shyly, attired in dark trousers, short white jackets, collar and bow tie (I like the Castilian for " bow tie," which is " tie of the little bird "). 
Pages I4 and I5 contain, under the general heading "Notebook of Personalities," the report of an interview with one of the patients at Fontilles. It is written in direct reporting style, and clearly reveals the life and heroism of Don Santiago Martín. The interview concludes, "Have you anything to add about your present life? " to which he replies, "To pray, to chat, and sing; all is reduced to this. I like to go to the chapel, I converse with my friends, and I keep on singing jotas."

On pages $I 6$ and $I 7$ with two photographs, there is a description of more visitors to Fontilles, this time of members of a Valencian religious association, with distribution of gifts, a game of football, and a grand festival in the square.

On page I7 there is another appeal on behalf of Fontilles. There is a quotation from St. John Chrysostome, followed by " Three hundred patients ask your aid: help Fontilles."

Pages I8 and I9 contain the description of the visit to Fontilles of the members of Radio Alcira, who came in a caravan of motors and motor-buses. There are two photographs. The Motoring Club of Alcira provided a vanguard of thirty motorcyclists, after which followed the ten motor-buses of the expedition. The gifted members of Radio Alcira gave a concert, toured the sanatorium, brought gifts, and even on returning to their coaches left two baskets full of monetary gifts. It must have been a magnificent occasion, the type of thing which one covets for our lonely sanatoria throughout the world.

Page 20 has another " sermonette," on the meaning of prayer, with three small pictorial illustrations. Page 2I has three photographs and a short description of a small happy picnic in Nazaret by a group of women patients, at the cost and invitation of some benefactors.

Page 22 has facts about Fontilles from the archives of forty years ago, when there where seventy-one patients. In that year a building was constructed to provide dining rooms for the patients, and other improvements were being carried out. On this page also there is another appeal for Fontilles. It begins with a quotation from Tobias, " Be charitable according to your ability. If you have much, give abundantly: if you have little, try to give with good will from the little you have, since thus you store up as treasure a great recompense for the day of your death." Then follows the appeal, "Fontilles stretches out its hand in the name of 300 leprosy patients." 
Page 23 has an historical note describing how the words of Queen Isabel the Catholic gave origin to the names of certain places. There are also advertisements, which get more frequent in the last pages of the magazine. Page 24 has "Three Columns" of events, men, and customs. This month the subjects are Argentina, the success of the play "La Muralla," and the inflated publicity of Hollywood.

On page 25 there is a Crossword Puzzle, in which the clues are not too abstruse, and the solutions are given printed upside down at the bottom of the page. On pages 27 to 32 there is the "Chronicle of Charity," in which detailed acknowledgement is made of all current gifts in money or kind to the sanatorium. Gifts in kind include such things as towels, sheets, clothes, shoes, chocolate, tobacco, sweets, reading matter, stockings etc.

On page 29 there is a selection of humorous stories, but the centre piece is a quotation from St. Paul, " Knowledge puffs up: charity builds up." The back cover gives a list of local treasurers in twenty-seven different centres, and the names of banks which will receive donations direct. "Fontilles" is published from Plaza de Tetuán, I8, bajos, Valencia, Spain.

That completes my picture of the June number of Fontilles: it speaks for itself, and I am sure it will be of deep interest to all who have to do with leprosy work. In order to round off the picture, I would like to point out that "Fontilles" has poetry too, and though there is no example in the June issue, there is much in previous numbers. I conclude with a translation of " $\mathrm{La}$ Noche " by María del Mar, in the March number of "Fontilles."

THE NIGHT

Midnight; the moon ashine

Of silver places on all things.

The frogs croak in the mud

And ceaselessly a cricket sings

Fontilles sleeps. Come dawnings

Of the warm dayspring.

Tell me, how many sorrows

Are veiled by this quiet night? 